\title{
A Research of the Cretaceous-Paleogene Boundary in the Pingyi Basin, Shandong Province
}

\author{
Jun Chen ${ }^{1,2,3} 3^{*}$, Shengxian Du1,2,3, Cheng Chen1,2,3, Fengchen Liu ${ }^{1,2,3}$, Zhengguo Ning4, \\ Xiangsuo Song1,2,3, Shucai Liu1,2,3, Huinan Lu' ${ }^{5}$, Yongqing Liu', Hongwei Kuang6
}

${ }^{1}$ Shandong Institute of Geological Sciences, Jinan, China

${ }^{2}$ Key Laboratory of Gold Mineralization Processes and Resources Utilization Subordinated to the Ministry of Land and Resources, Jinan, China

${ }^{3}$ Key Laboratory of Metallogenic Geological Process and Resources Utilization in Shandong Province, Jinan, China

${ }^{4}$ Shandong Institute of Geological Survey, Jinan, China

${ }^{5}$ Nanjing Institute of Geology and Palaeontology, Chinese Academy of Sciences, Nanjing, China

${ }^{6}$ Insititute of Geology, Chinese Academy of Geological Sciences, Beijing, China

Email: *chenjun1987111@163.com, dushengxian@126.com, chencheng307@163.com

How to cite this paper: Chen, J., Du, S.X., Chen, C., Liu, F.C., Ning, Z.G., Song, X.S., Liu, S.C., Lu, H.N., Liu, Y.Q. and Kuang, H.W. (2019) A Research of the Cretaceous-Paleogene Boundary in the Pingyi Basin, Shandong Province. Open Journal of Geology, 9, 661-664. https://doi.org/10.4236/ojg.2019.910068

Received: August 16, 2019

Accepted: September 21, 2019

Published: September 24, 2019

Copyright $\odot 2019$ by author(s) and Scientific Research Publishing Inc. This work is licensed under the Creative Commons Attribution International License (CC BY 4.0).

http://creativecommons.org/licenses/by/4.0/

\section{cc) (i) Open Access}

\begin{abstract}
The Bianqiao Formation (in the Pingyi Basin, Shandong Province, China) is a typical set of continuous lacustrine carbonate deposits during the Cretaceous-Paleogene period, which is considered as an ideal stratigraphic unit for KPB research. This study is based on the borehole PYZK01, which is located at Tongjiazhuang village in Bianqiao Town of Pingyi country. According to biostratigraphy research, the Bianqiao Formtion establishes one charophyte assemblage: Porocharaanluensis-Charayuntaishanensis var. acuta-Turbocharaspecialis, and one sporopollen assemblage: Deltoidosporaadriensis-RugubivesiculitesSchizaeoisporites. This result indicates that the stratigraphic age during 0 $12.25 \mathrm{~m}$ is the Paleogene, $37.8 \mathrm{~m}-60 \mathrm{~m}$ is the Late Cretaceous, and 12.25 $37.8 \mathrm{~m}$ is a transition stage from the Late Cretaceous to the Paleocene. By geochemical study, it was established carbon and oxygen isotopic strata in the drill. Through the magnetostratigraphy research, we find eight positive polarity zones and seven reversed polarity zones, build the magnetic polarity sequences of the borehole, and propose a contrast scheme with the international standard magnetic polarity time column. After comprehensive discussion, it is preliminarily believed that the Cretaceous-Paleogene boundary is located at the depth of $31.98 \mathrm{~m}$ in PYZK01, namely, in the first section of the Bianqiao Fm.
\end{abstract}

\section{Keywords}

Cretaceous-Paleogene Boundary, Biostratigraphy, Isotopic Stratigraphy, 
Magnetostratigraphy, Pingyi Basin

At the turn of the Cretaceous and the Paleogene, major events occurred all over the world, such as the mass extinction of dinosaur and the rise of mammals, and the research of the Cretaceous-Paleogene boundary has become a hotspot. Although the research of KPB has made important progress, many important problems still have not been solved in non-marine stratigraphy [1] [2] [3] [4]. So the establishment of the non-marine Cretaceous-Paleogene boundary stratigraphy is necessary. The Bianqiao Fm of the Guanzhuang Group in the Pingyi Basin of Shandong Province is a typical set of fluvial and lacustrine deposits, mainly consisted of carbonate rocks and gypsum ore beds, near the Mesozoic-Cenozoic boundary in China. Besides, it is also one of the strata units with the largest thickness of continuous sedimentary limestone in continental lacustrine basins in the same period in our country, which contains very important geological information, such as biological, sedimentary, and terrestrial carbonate lake basin evolution. Much great progress has been made in KPB [5] [6] [7] [8] [9]. Based on previous work, we conduct a comprehensive study on biostratigraphy, isotopic stratigraphy, and magnetic stratigraphy of PYZK01, which is the first time in the region.

In terms of petrostratigraphy, it is continuous that the whole lithology shows a set of sedimentary characteristics with alternating shore-shallow lacustrine facies and shallow lacustrine facies. From the perspective of sedimentary environment, the lithology mainly consists of gray, purple and flesh-red limestone and marl, indicating the dry and hot palaeoclimate environment. However, reductive environmental strata represented by dark sediments no longer appeared above $31.57 \mathrm{~m}$, showing obvious rapid changes or abrupt events of sedimentary environment and paleocaterium, which may be related to geological events at the turn of the Cretaceous to the Paleogene.

In terms of biostratigraphy, we obtain abundant fossils of chardonophytes, palynophytes, metamorphoses and gastropods. Among them, Sphaerochara cf. chinensis (Huang et $\mathrm{Xu}$ ) was found at $12.25 \mathrm{~m}$, indicating that the strata shallower than $12.25 \mathrm{~m}$ are not earlier than the Paleogene. The charophyte assemblage of Porocharaanluensis-Charayuntaishanensis var. acuta-Turbocharaspecialis indicates that the stratigraphic age deeper than $40.03 \mathrm{~m}$ was determined as the late Late Cretaceous, and it is also further confirmed by the palynological assemblage of Deltoidosporaadriensis-Rugubivesiculites-Schizaeoisporites from $37.8 \mathrm{~m}$ to $40.3 \mathrm{~m}$ and the gastropod fossils from $37.8 \mathrm{~m}$ to $57.5 \mathrm{~m}$. Thus, the KPB is limited of $12.25 \mathrm{~m}$ to $37.8 \mathrm{~m}$ by biostratigraphy.

In terms of magnetostratigraphy, we find eight positive polarity zones and seven reversed polarity zones, build the magnetic polarity sequences of the borehole, and propose a contrast scheme with the international standard magnetic polarity time column. The KPB was further restricted to the third reverse polarity zone which is from $25.7 \mathrm{~m}$ to $37.6 \mathrm{~m}$, and a significant negative drift of the 
susceptibility curve occurred at the depth of $31.98 \mathrm{~m}$.

In terms of isotopic strata, carbon and oxygen isotopic strata were established, and an obvious phenomenon of oxygen isotopic curve positive drift and carbon isotopic curve negative drift also appeared at $31.98 \mathrm{~m}$.

Based on the above results, the Bianqiao Fm in the Pingyi Basin has the Cretaceous-Paleogene boundary, and its location is basically confirmed to $31.98 \mathrm{~m}$ deep in PYZK01, namely, in the first section of the Bianqiao Fm.

\section{Acknowledgements}

This study was supported by the China Geological Survey Project "Study on Shandong Paleogene Stratigraphic Division Comparative" (1212011120146) and Major Innovative Project of Shandong Province "Exploration and Exploitation of Deep Earth Resources" and "Study on oil and gas occurrence conditions in the Riqingwei Basin in east sea of Shandong province" (2017CXGC1608), "Deep structure of Yishu fault zone and its impact on resources and environment" (2017CXGC1602). This is a contribution to UNESCO-IUGS IGCP Project 679.

\section{Conflicts of Interest}

The authors declare no conflicts of interest regarding the publication of this paper.

\section{References}

[1] Zhang, X.Q. and Li, G. (2008) Ostracod Faunas from the Luofozhai Group in the Nanxiongbasin of Guangdong Province, China. Acta Micropalaeontologica Sinica, 25, 44-77.

[2] Sun, G., Quan, C., Sun, C.L., Sun, Y.W., Luo, K.L. and Lv, J.S. (2005) Some New Knowledge on Subdivisions and Age of Wuyun Formationin Jiayin of Heilongjiang, China. Journal of Jilin University (Earth Science Edition), 35, 137-142.

[3] Chen, P.J., Wan, X.Q., Liu, G.W., Cao, M.Z., Wang, Q.F., Cao, L., Li, G. and Wang, Y.Q. (2012) On the Geological Age of the Furaoan Stage. Journal of Stratigraphy, 36, 755-772.

[4] Wan, X.Q., Zhao, J., Scott, R.W., Wan, P.J., Feng, Z.H., Huang, Q.H. and Xi, D.P. (2013) Late Cretaceous Stratigraphy, Songliao Basin, NE China: SK1 Cores. Palaeogeography, Palaeoclimatology, Palaeoecology, 385, 31-43. https://doi.org/10.1016/j.palaeo.2012.10.024

[5] Li, S.J., Zheng, D.S., Cai, J.G., Yang, Y.H., Sun, X.W. and Yang, P.R. (2003) Sedimentary Chaiacteritics and Controlling Factors of Basins in the North Shandong and Southwest Shandong in Paleogene. Geological Review, 49, 225-232.

[6] Du, S.X., Liu, F.C., Chen, J., Gao, L.M., Song, X.S., Chen, C., Tian, X.L., Zhang, Z.Q. and Liu, S.C. (2019) The Cretaceous-Paleocene Biostratigraphy and Boundary in the Pingyi Basin, Shandong Province. Acta Geologica Sinica, 93, 1831-1848.

[7] Yu, X.F., Du, S.X., Wang, Q.F., Liu, S.C., Zhou, L., Liu, F.C., Lu, H.N. and Chen, C. (2014) Late Cretaceous Ostracods from the Pingyi Basin, Shandong Province, China. Acta Micropalaeontogical Sinica, 31, 387-404.

[8] Zhang, Z.Q., Du, S.X., Zhang, S.K., Lu, H.N., Liu, S.C., Gao, L.M., Song, X.S., Yang, 
N., Liu, F.C., Zhou, L., Chen, C. and Chen, J. (2014) Reassessment of the Guanzhuang Group in the Pingyi Basin, Shandong. Journal of Stratigraphy, 38, 8-24.

[9] Li, S., Wang, Q.F., Zhang, H.C., Lu, H.N. and Closas, C.M. (2016) Charophytes from the Cretaceous-Paleogene Transition in the Pingyi Basin (Eastern China) and Their Eurasian Correlation. Cretaceous Research, 59, 179-200.

https://doi.org/10.1016/j.cretres.2015.10.022 